\title{
The Degradation Behavior of TPS/LDPE Blend Mulch Films Prepared with Different Pro-oxidants
}

\section{Farklı Pro-oksidanlar ile Üretilmiş TPN/AYPE Karışım Malç Filmlerin Bozunma Davranışı}

\author{
Research Article
}

\author{
Elif Vargun ${ }^{1 *}$, Zekiye Sisli ${ }^{2}$, Ferah Yilmaz ${ }^{3}$, Hayrünisa Baş Sermenli ${ }^{4}$ \\ 'Department of Chemistry, Muğla Sıtkı Koçman University, Muğla. \\ 2Department of Chemistry, Middle East Technical University, Ankara. \\ ${ }^{3}$ Mushroom Research Centre, Muğla Sıtkı Koçman University, Muğla. \\ ${ }^{4}$ Department of Biology, Muğla Sıtkı Koçman University, Muğla.
}

\section{A B S TRACT}

ow density polyethylene (LDPE) was blended with thermoplastic starch (TPS) by twin screw compounder to _ prepare partially degradable mulch films. In the present study, ferric stearate and manganese(II) stearate were used as pro-oxidant and the effect of different pro-oxidants on the degradation of the blends were investigated. The blended mulch films were buried in soil inoculated with Coriolus versicolor (L.) Quél. for 180 days for the degradation. The chemical structures of the films were evaluated by FTIR spectroscopy and the weight loss of all samples was measured before and after soil burial treatment. The effects of two different pro-oxidants on thermal and tensile properties of blends were determined by TGA and mechanical analysis. A synergetic effect between ferric stearate and citric acid was observed. Using both in the blends resulted in higher thermal stability of TPS in the blends. Significant improvement of the mechanical properties was also observed. However, when manganese(II) stearate used together with citric acid a decrease in the mechanical properties was observed compared blends with stearic acid.

\section{Key Words}

LDPE, thermoplastic starch, pro-oxidant, ferric stearate, manganese(II) stearate.

\section{Ö Z}

K ısmen bozunabilen malç filmleri hazırlamak için az yoğunluklu polietilen (AYPE), termoplastik nişasta (TPN) ile çift vidalı ekstruder yardımıyla karıştıııldı. Bu çalışmada, demir(III) stearat ve manganez(II) stearat pro-oksidan olarak kullanılmışve farklı pro-oksidanların karışımların bozunması üzerindeki etkisi incelenmiştir. Malç filmler Coriolus versicolor (L.) Quel ile aşılanmış toprağa gömülerek 180 gün boyunca degrede edilmiştir. Filmlerin kimyasal yapıları FTIR spektroskopisi ile belirlenmiş ve tüm numunelerin ağırlık kaybı toprakta bozunma öncesi ve sonrası ölçülmüştür. İki farklı pro-oksidanın, malç karışımların ısıl ve germe özellikleri üzerine etkisi TGA ve mekanik analiz ile tespit edilmiştir. Demir (III) stearat ve sitrik asitin birlikte kullanılmasıyla sinerjik bir etki gözlenmiştir. Her ikisinin birlikte kullanıldığı karışımlarda TPN'nin yüksek ısıl kararlılık gösterdiği bulunmuştur. Ayrıca, mekanik özelliklerinde belirgin düzelme gözlenmiştir. Bununla birlikte, manganez(II) stearat sitrik asit ile birlikte kullanıldığında stearik asitli karışımlarına kıyasla daha zayıf mekanik özellikler göstermiştir.

\section{Anahtar Kelimeler}

AYPE, termoplastik nişasta, pro-oksidan, demir stearat, manganez(II) stearat.

Article History: Received: Mar 2, 2016; Revised: Jun 12, 2016; Accepted: Sep 20, 2016; Available Online: Apr 1, 2017.

DOI: 10.15671/HJBC.2017.155

Correspondence to: E. Vargun, Department of Chemistry, Mugla Sitki Kocman University, Kötekli Muğla, Turkey. 


\section{INTRODUCTION}

ow density polyethylene (LDPE) and its copolymers have been widely used in agricultural purposes such as greenhouses, low tunnel and mulching films. Mulching is the practice of covering the top of the soil with a plastic film as has been done by leaves or straw in nature. The mulch films are mostly made from LDPE and the mulch films which are spread over large areas and then removed from the field after the harvest [1]. When the film was left in the soil do not degrade and stay in the soil as a macro pollutants [2]. Degradable mulch films may offer an economical alternative and become a solution for ultimate disposal problem. Starch has potential to provide a solution to environmental concerns, the mixing of starch with the matrix of LDPE, can cause the degradation of LDPE partially. The native starch is converted to the thermoplastic starch (TPS) by using glycerol and water for better distribution in LDPE [3]. Blending TPS with LDPE enhances the accessibility of the LDPE to oxygen and microorganisms. To initiate and propagate radical degradation, the special additives called pro-oxidants can be added to the blend system. Pro-oxidants are transition metal (Fe, Co, Mn) complexes of stearate or acetyl acetonate ligands and they accelerate the photoor thermo-oxidation. After the decomposition of peroxides, radical chain reactions start, as a result chains are shortened and molecular weight was decreased [4]. Many researchers suggest fungi inoculation in soil to accelerate this degradation process of polyethylene/starch blends. Fungi play vital role in biomass degradation in nature. Orhan and Büyükgüngör evaluated the biodegradation of LDPE/starch blend films in Phanerochaete chrysosporium (ATCC 34541) inoculated soil for 6 months and they showed that inoculation of soil with $P$. chrysosporium enhances the biodegradation of LDPE/starch blend [5]. The biodegradability of maleic anhydride grafted LLDPE/starch blends have been investigated in mixed fungi inoculum. Blends were placed in sterile petri dishes containing spores of Aspergillus niger, Penicilliurn funiculosum, Chaetomium globosum, Gliocladiurn virens and Pullularia pullulans [6].

In our previous study, cobalt(II)acetyl acetonate pro-oxidant added TPS/LDPE blends were degraded in two different fungi (Coriolus versicolor (L.) Quél. and Postia placenta (Fr.) M.J. Larsen \& Lombard) inoculated soil for 180 days [7]. It was found that the efficieny of Coriolus versicolor in weight loss was better than Postia placenta and Coriolus versicolor containing soil environment had a profound effect on the decrease in tensile strength of films. In this study, the soil was inoculated with one type of fungi (Coriolus versicolor (L.) Quél) and two different types of pro-oxidants were used. The effects of ferric stearate and manganese(II) stearate prooxidants on degradation of TPS/LDPE blends were compared by weight loss, FTIR spectroscopy, thermogravimetric analysis and mechanical tests.

\section{EXPERIMENTAL}

\section{Materials}

LDPE (F2-12 grade) was supplied by Turkish Petrochemical Industry, PETKIM. The wheat starch (Sigma-Aldrich), ferric stearate (MP Biomedicals) and manganese(II) stearate (90\%, Santa Cruz Chemicals) were used as received. The glycerol of reagent grade with purity $99.5 \%$, the compatibilizers stearic acid with purity $95 \%$ and citric acid with purity $99 \%$ were obtained from Sigma-Aldrich and they were all used as received.

\section{Sample Preparation}

TPS/LDPE blend films were prepared as reported earlier [7]. In brief, to prepare thermoplastic starch (TPS), the 48\% wheat starch, 33\% glycerol and $19 \%$ deionized water by weight were mixed and heated for $8-10$ minutes at $70-75^{\circ} \mathrm{C}$ and then dried at $60^{\circ} \mathrm{C}$ in vacuum oven for 48 hours. After the TPS was prepared, LDPE, ferric stearate and manganese(II) stearate pro-oxidants, citric acid and stearic acid compatibilizers were blended. The compositions contain $20 \%, 30 \%$, and $40 \%$ of TPS by weight according to total weight of LDPE and TPS. The amount of pro-oxidant (ferric stearate or manganese(II) stearate) in each composition equals to $0.5 \%$ and the amount of compatibilizer (stearic acid or citric acid) equals to $2 \%$ by weight according to total weight of LDPE and TPS. The compositions of different blends prepared in this study are shown in Table 1. 
Table 1. The recipe of materials used for blends prepared by extrusion.

\begin{tabular}{|c|c|c|c|c|c|c|c|c|c|c|c|}
\hline \multirow[b]{2}{*}{ Code } & \multicolumn{2}{|c|}{ TPS+LDPE } & \multicolumn{2}{|c|}{ Compatibilizer } & \multirow{2}{*}{$\begin{array}{c}\begin{array}{c}\text { Pro- } \\
\text { oxidant }\end{array} \\
\text { Ferric } \\
\text { stearate }\end{array}$} & \multirow[b]{2}{*}{ Code } & \multicolumn{2}{|c|}{ TPS+LDPE } & \multicolumn{2}{|c|}{ Compatibil. } & \multirow{2}{*}{$\begin{array}{l}\text { Pro-oxidant } \\
\text { Manganese } \\
\text { (II) stearate }\end{array}$} \\
\hline & $\begin{array}{l}\text { TPS } \\
(\%)\end{array}$ & $\begin{array}{c}\text { LDPE } \\
(\%)\end{array}$ & $\begin{array}{l}\text { Citric } \\
\text { Acid } \\
(\%)\end{array}$ & $\begin{array}{c}\text { Stearic } \\
\text { Acid } \\
(\%)\end{array}$ & & & $\begin{array}{l}\text { TPS } \\
(\%)\end{array}$ & $\begin{array}{c}\text { LDPE } \\
(\%)\end{array}$ & $\begin{array}{l}\text { Citric } \\
\text { acid } \\
(\%)\end{array}$ & $\begin{array}{c}\text { Stearic } \\
\text { acid } \\
(\%)\end{array}$ & \\
\hline W20 & 20 & 80 & - & - & - & W20 & 20 & 80 & - & - & - \\
\hline W2OF & 20 & 80 & - & - & $0.5 \%$ & W20M & 20 & 80 & - & - & $0.5 \%$ \\
\hline W20Fca & 20 & 80 & 2 & - & $0.5 \%$ & W20Mca & 20 & 80 & 2 & - & $0.5 \%$ \\
\hline W20Fsa & 20 & 80 & - & 2 & $0.5 \%$ & W20Msa & 20 & 80 & - & 2 & $0.5 \%$ \\
\hline W30 & 30 & 70 & - & - & - & W30 & 30 & 70 & - & - & - \\
\hline W30F & 30 & 70 & - & - & $0.5 \%$ & W30M & 30 & 70 & - & - & $0.5 \%$ \\
\hline w30Fca & 30 & 70 & 2 & - & $0.5 \%$ & W30Mca & 30 & 70 & 2 & - & $0.5 \%$ \\
\hline w30Fsa & 30 & 70 & - & 2 & $0.5 \%$ & W30Msa & 30 & 70 & - & 2 & $0.5 \%$ \\
\hline W40 & 40 & 60 & - & - & - & W40 & 40 & 60 & - & - & - \\
\hline W40F & 40 & 60 & - & - & $0.5 \%$ & W40M & 40 & 60 & - & - & $0.5 \%$ \\
\hline W40Fca & 40 & 60 & 2 & - & $0.5 \%$ & W40Mca & 40 & 60 & 2 & - & $0.5 \%$ \\
\hline W40Fsa & 40 & 60 & - & 2 & $0.5 \%$ & W40Msa & 40 & 60 & - & 2 & $0.5 \%$ \\
\hline
\end{tabular}

To prevent confusion about types of blends, they are coded as e.g. W4OFsa, where "W" represents thermoplastic wheat starch, the number " 40 " written represents the $40 \%$ of starch by weight, the " $F$ " represents the Ferric stearate and the "sa" represents the stearic acid (and also "ca" represents the citric acid). A control group is composed of three samples, containing $20 \%$, $30 \%$ and $40 \%$ of TPS without pro-oxidants and compatibilizers in order to see the effects of these chemicals' influence on mechanical properties and degradation rates of the samples. Blends were prepared by DSMxplore Netherlands, micro $15 \mathrm{cc}$ twin screw compounder. The temperatures of the three zones were $145^{\circ} \mathrm{C}-150^{\circ} \mathrm{C}-145^{\circ} \mathrm{C}$. The screw speed was $100 \mathrm{rpm}$ and the die temperature was $138^{\circ} \mathrm{C}$. The blends were compression moulded in Pneumo Hydraulic Press at $150^{\circ} \mathrm{C}$ for 4 minutes and the films prepared are stored at $4^{\circ} \mathrm{C}$ for further investigation.

\section{Characterization}

FTIR analyses were performed with BRUKER VERTEX 70 model FTIR Spectroscopy for the chemical characterization of the blends. FTIR spectra of all samples were recorded by using ATR technique with a resolution of $16 \mathrm{~cm}^{-1}$ and number of 32 scans per sample in a spectral range of $4000-600 \mathrm{~cm}^{-1}$. The FTIR spectra of the samples were recorded before and after soil burial treatment. Perkin-Elmer, Pyris model Thermo gravimetric analyser was used to characterize the degradation behavior of samples. The TGA analyses of samples were carried out in the nitrogen atmosphere at heating rate of $10^{\circ} \mathrm{C} /$ min from $25^{\circ} \mathrm{C}$ up to $600^{\circ} \mathrm{C}$. Tensile strength and percentage strain were measured by LLYOD LR $5 \mathrm{~K}$ at room temperature with crosshead speed of $50 \mathrm{~mm} / \mathrm{min}$. The six specimens were tested for each blend. The thicknesses of the films were 100 microns. The mechanical properties of the films were measured before and after soil burial.

\section{Soil Preparation and Inoculation}

The soil was collected from farmland soil on Yeşilyurt/Muğla. The soil was sieved ( $<2 \mathrm{~mm}$ ) and stored at $4^{\circ} \mathrm{C}$ sealed in plastic container. The Coriolus versicolor (L.) Quél. (COV-1030- from Wood Research Institute, Kyoto University) fungi which were maintained through periodic transfer at $4^{\circ} \mathrm{C}$ on petri dishes containing $20 \mathrm{~g}$ malt extract and $15 \mathrm{~g}$ agar (both from Merck) per one liter of water. Freshly prepared agar plates were inoculated with a $1-\mathrm{cm}$ diameter plug of C.versicolor, taken from the edge of an actively growing colony and incubated at $27^{\circ} \mathrm{C}$ until the 
plates were sufficiently covered with mycelium. Incubation were carried out $27^{\circ} \mathrm{C}$ in the dark by pre inoculating $300 \mathrm{ml}$ of potato dextrose broth $(24 \mathrm{~g} / \mathrm{l})$ containing $0.5 \%$ yeast extract in $500 \mathrm{ml}$ shaken flasks with a $4 \times 1-\mathrm{cm}$ diameter plug of the C.versicolor mycelia. $50 \mathrm{ml}$ of a 5-day-old culture were transferred in 1 liter flasks containing $450 \mathrm{ml}$ of broth. The cultures were incubated in the dark at $27^{\circ} \mathrm{C}$. After $10-12$ day of incubation, the fungal cultures were ready to be inoculated aseptically in soil.

\section{Soil Burial}

The plastic box having approximate dimensions $25 \mathrm{~cm} \times 19 \mathrm{~cm} \times 33 \mathrm{~cm}$ were filled with the sieved soil. The sterile blended film samples were cut into pieces with dimensions $6 \times 7 \mathrm{~cm}$ and buried in fungi inoculated or uninoculated soil at the depth of $8 \mathrm{~cm}$ and stored in a sterilized chamber at $24^{\circ} \mathrm{C}$ and $40 \%$ relative humidity. The soil was fed with $3 \mathrm{~K}$ basal mineral solution containing $\mathrm{KH}_{2} \mathrm{PO}_{4}, 0.7$; $\mathrm{K}_{2} \mathrm{HPO}_{4}, 0.7 ; \mathrm{MgSO}_{4} .7 \mathrm{H}_{2} \mathrm{O}, 0.7 ; \mathrm{NH}_{4} \mathrm{NO}_{3}, 1.0 ; \mathrm{NaCl}$ $0.005 ; \mathrm{MnSO}_{4} .7 \mathrm{H}_{2} \mathrm{O}, 0.001 ; \mathrm{ZnSO}_{4} .7 \mathrm{H}_{2} \mathrm{O}, 0.002$; $\mathrm{FeSO}_{4}, 0.002$; in terms of gram per liter, at $\mathrm{pH}$ 6.5 [5]. The specimens were taken from the soil and the soil was removed for the weight loss measurements. Weight loss of the specimens with time was used to measure the degradation rate in the soil. Before burial and 180 days after the burial, the weights of the specimens were measured and recorded.

\section{Weight Loss}

The blend films were weighed by analytical balance before degradation and after soil treatment samples were recovered, washed, dried and weighed and the weight loss was determined by using the below Equation 1;

Percentage Weight Loss $=\frac{(\text { Weight } \text { initial }- \text { Weight final })}{\text { Weight } \text { initial }} \times 100$

\section{RESULTS and DISCUSSION}

\section{FTIR Analysis Before Soil Burial Treatment}

The chemical structures of the films were identified by ATR-FTIR spectroscopy. The FTIR spectra of $40 \%$ of TPS containing blends are given in Figure 1 and Figure 2 for ferric stearate and manganese(II) stearate pro-oxidants,

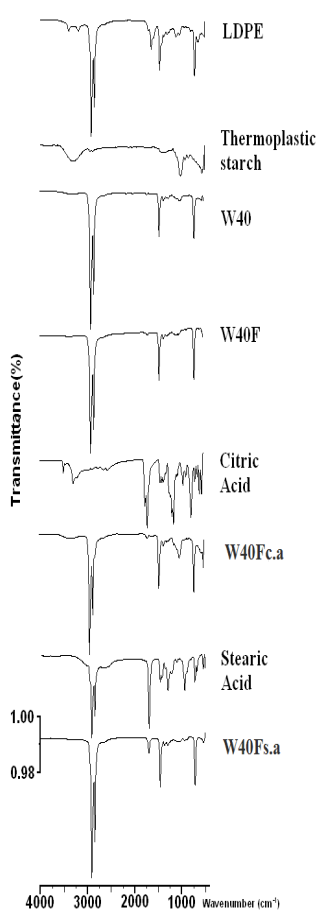

Figure 1. FTIR spectra of W4OF, W4OFca and W4OFsa.

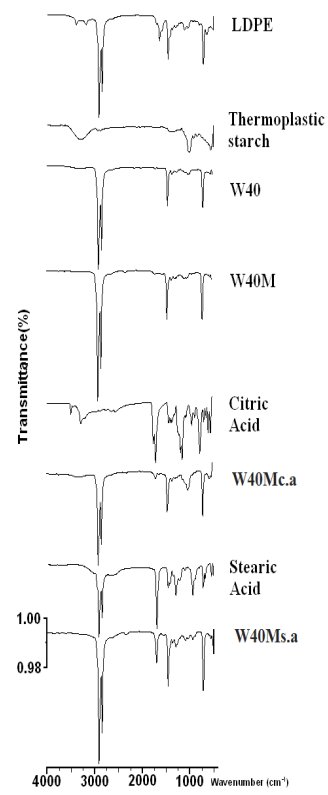

Figure 2. FTIR spectra of W40M,W40Mca and W40Msa.

respectively. In the spectrum of the LDPE, the characteristic $-\mathrm{CH}_{2}$ asymmetric and symmetric stretching can be seen around 2918 and 2840 $\mathrm{cm}^{-1}$, respectively. The $-\mathrm{CH}_{2}$ bending and $-\mathrm{CH}_{2}$ rocking gave peaks at around $1461-1301 \mathrm{~cm}^{-1}$ and $712 \mathrm{~cm}^{-1}$, respectively. The characteristic bands for 

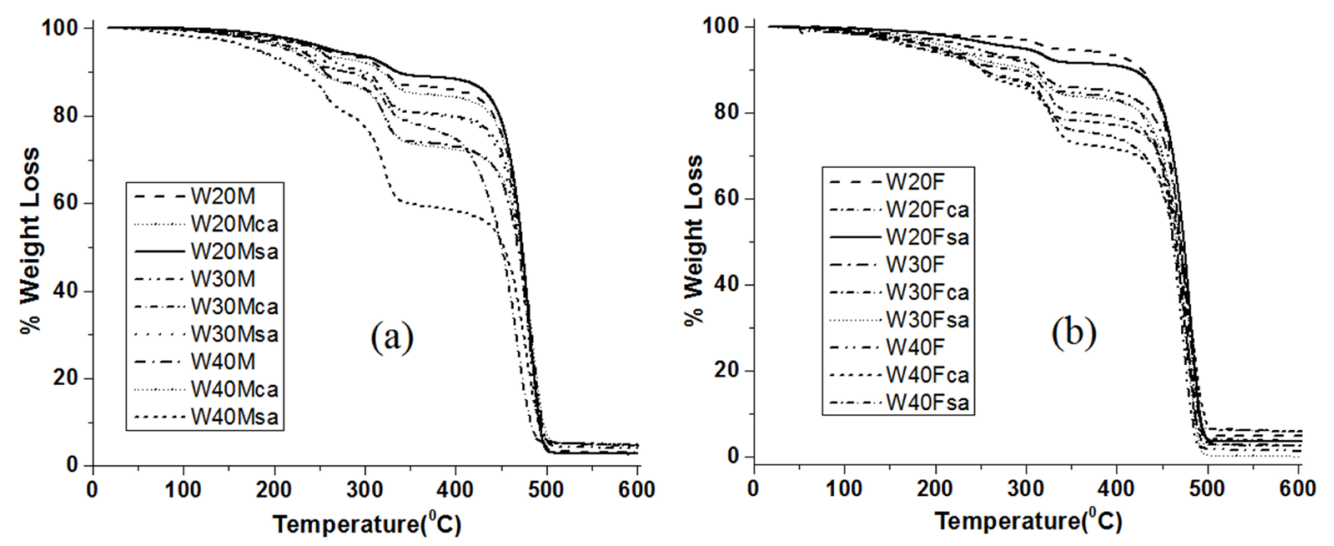

Figure 3. TGA curves of the blends before soil burial, a) manganese(II) stearate group, b) ferric stearate group.

thermoplastic starch can also be seen in Figure 1 and Figure $2 \mathrm{~A}$ broad $\mathrm{O}-\mathrm{H}$ stretching absorbance in the $3289 \mathrm{~cm}^{-1}$ region and strong $\mathrm{C}-\mathrm{O}$ stretching peak at the $1020 \mathrm{~cm}^{-1}$ were identified. All the characteristic peaks of LDPE $(2918,2844,1464$ and $\left.719 \mathrm{~cm}^{-1}\right)$ and starch $\left(3309 \mathrm{~cm}^{-1}\right.$ and $\left.1026 \mathrm{~cm}^{-1}\right)$ units have appeared in the $\mathrm{W} 40$ blend. The citric acid and stearic acid were added as compatibilizer and the characteristic $-\mathrm{C}=\mathrm{O}$ group of stearic acid was seen at $1702 \mathrm{~cm}^{-1}$ (Figure 1) for W4OFsa blend. The peak at $1710 \mathrm{~cm}^{-1}$ was related to the carbonyl group of citric acid in the spectrum of W40Mca (Figure 2). Prooxidants accelerates the photo and thermooxidation of the polymers, so consequent polymer chain cleavage makes the polymer more susceptible to biodegradation. Thus, ferric stearate and manganese(II) stearate were added to the LDPE/starch blends and the spectra comprising a blend of LDPE, starch ferric stearate and manganese(II) stearate can be seen in Figure W40F and Figure W40M, respectively.

\section{Thermogravimetric Analysis Before Soil Burial} Treatment

The degradation temperatures and the weight loss patterns during thermal degradation of neat LDPE and neat TPS were performed in our previous study [7]. The TGA curves revealed that, pure LDPE indicates one stage of degradation $\left(490^{\circ} \mathrm{C}\right)$, whereas thermoplastic starch showed three decomposition stages $\left(100^{\circ} \mathrm{C}, 210^{\circ} \mathrm{C}\right.$ and $321^{\circ} \mathrm{C}$ ). The first stage (at $100^{\circ} \mathrm{C}$ ) corresponds to the absorbed water, the second one $\left(210^{\circ} \mathrm{C}\right)$ attributed to the glycerol evaporation and the last degradation stage $\left(321^{\circ} \mathrm{C}\right)$ was observed due to the decomposition of starch. In the present study, the TGA curves of manganese (II) stearate group and ferric stearate group are displayed Figures $3 a$ and $3 b$, respectively. The decomposition

Table 2. The decomposition temperatures for the blends before soil burial treatment.

\begin{tabular}{cccccccc}
\hline $\begin{array}{c}\text { Code } \\
\text { of the } \\
\text { sample }\end{array}$ & $\begin{array}{c}\text { Evaporation } \\
\text { Temperature } \\
\text { of Glycerol } \\
\left({ }^{\circ} \mathrm{C}\right)\end{array}$ & $\begin{array}{c}\text { Decompo. } \\
\text { Temperature } \\
\text { of Starch }\left({ }^{\circ} \mathrm{C}\right)\end{array}$ & $\begin{array}{c}\text { Decompo. } \\
\text { Temperature } \\
\text { of LDPE }\left({ }^{\circ} \mathrm{C}\right)\end{array}$ & $\begin{array}{c}\text { Code } \\
\text { of the } \\
\text { sample }\end{array}$ & $\begin{array}{c}\text { Evapor. } \\
\text { Temp. of } \\
\text { glycerol }\left({ }^{\circ} \mathrm{C}\right)\end{array}$ & $\begin{array}{c}\text { Decomp. } \\
\text { Temp. of } \\
\text { starch }\left({ }^{\circ} \mathrm{C}\right)\end{array}$ & $\begin{array}{c}\text { Decomp. } \\
\text { Temp. of } \\
\text { LDPE } \\
\left({ }^{\circ} \mathrm{C}\right)\end{array}$ \\
\hline W20M & 259 & 322 & 481 & W2OF & - & 319 & 478 \\
\hline W20Mca & 245 & 326 & 481 & W2OFca & - & 328 & 479 \\
\hline W20Msa & 261 & 324 & 481 & W2OFsa & - & 319 & 479 \\
\hline W30M & 259 & 321 & 481 & W3OF & 247 & 319 & 479 \\
\hline W30Mca & 241 & 326 & 473 & W30Fca & 242 & 328 & 477 \\
\hline W30Msa & 259 & 325 & 481 & W30Fsa & 247 & 319 & 477 \\
\hline W40M & 251 & 321 & 481 & W40F & - & 327 & 475 \\
\hline W40Mca & 238 & 321 & 481 & W4OFca & 249 & 330 & 481 \\
\hline W40Msa & 254 & 321 & 477 & W4OFsa & 251 & 321 \\
\hline
\end{tabular}



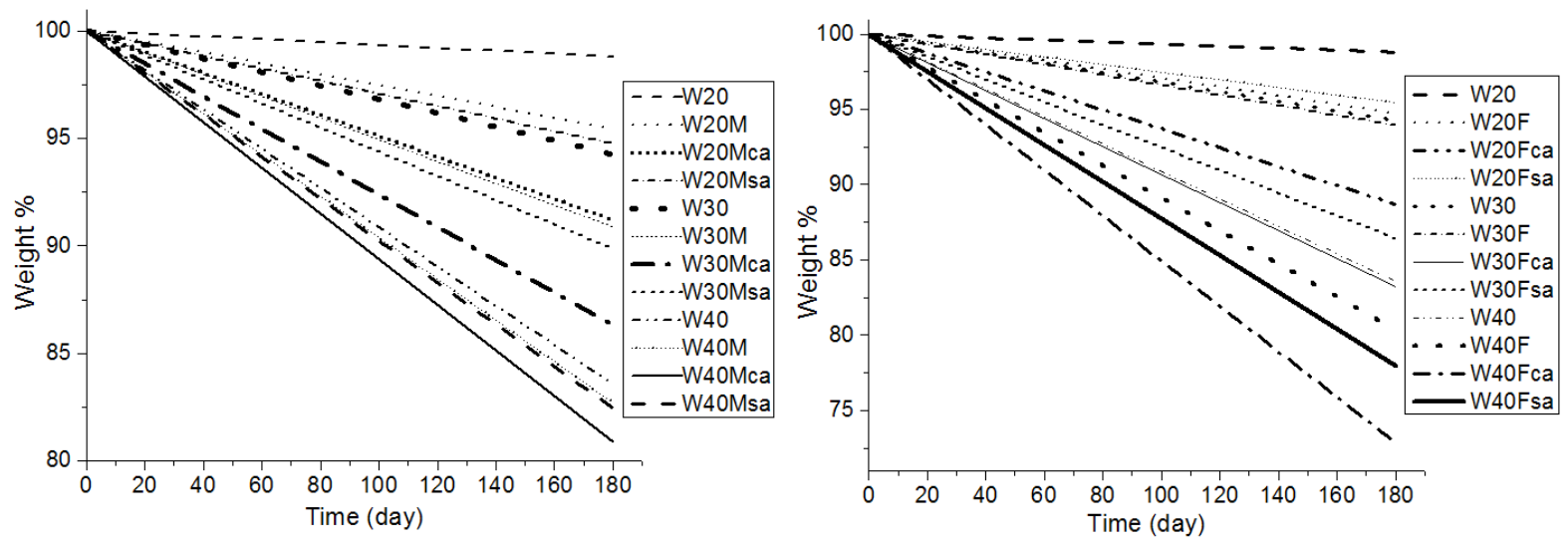

Figure 4. The percentage weight of the blend films versus time, a) manganese(II) stearate group, b) ferric stearate group.

temperatures of both prooxidants are given in the Table 2. Four well defined weight loss stages were observed for all blends, except for the W20F, W2OFca and W20Fsa blends. For these 20\% of TPS loaded ferric stearate group, three well defined weight loss stages can be observed and the mass loss which was attributed to evaporation of glycerol was not observed (Table 2). The TGA thermograms of both prooxidant groups showed that the decomposition temperatures of TPS and LDPE were changed in blends. The starch was degraded at around $321-326^{\circ} \mathrm{C}$ for manganese (II) stearate group and at $319-330^{\circ} \mathrm{C}$ for ferric stearate group. These values are higher than the degradation temperature of neat starch, which was $321{ }^{\circ} \mathrm{C}$. Besides that, the decomposition temperature of the neat LDPE was lowered from $490^{\circ} \mathrm{C}$ to $473-481^{\circ} \mathrm{C}$ for the both prooxidant group blends. It was also found that the citric acid increased the thermal stability of starch when compared with the stearic acid. In addition to that, citric acid lowered the evaporation temperature of glycerol since the citric acid can form stronger hydrogen bonds with starch than glycerol and then glycerol became free.

When the thermal stabilities of the starch in the blends are compared, it is obvious that prooxidants play an important role in this case. When ferric stearate used together with citric acid, a significant increase in the thermal stability of the starch was observed. Addition of manganese (II) stearate had a moderate effect on the thermal stability of starch in the blends. When stearic acid is used together with this prooxidant a slight increase in the thermal stability of the starch in the blends. This effect was a result of high similarity between the structures of stearic acid and manganese(II) stearate.

\section{Soil Burial Treatment}

The blend films were degraded in Coriolus versicolor inoculated soil for 180 days. After the soil burial, the characterizations were carried out in terms of their gravimetric (weight loss), thermogravimetric and mechanical properties. The chemical structures of TPS/LDPE blend films were also characterized by FTIR spectroscopy after the degradation.

\section{Weight Loss Records for the Blends}

The percentage weights of the films are displayed in Figure $4 a$ and Figure $4 b$, which corresponds to the manganese (II) stearate group and ferric stearate group, respectively. The graphs were plotted according to the formula given in Equation1. The degradation of manganese (II) stearate prooxidant added TPS/LDPE blend films in Coriolus versicolor inoculated soil was compared with the degradation of ferric stearate pro-oxidant added TPS/LDPE blend films. For both pro-oxidant groups, it is evident that increasing starch content resulted in increasing weight loss. In high TPS containing blends, a very small part of TPS was surrounded by LDPE and the dispersed parts of TPS became more interconnected and continuous. Hence, for high loadings for starch more possible substrates were created for the microorganism attacks. The weight loss of the films with ferric stearate pro-oxidant were higher than that of the manganese (II) stearate group. In ferric stearate group, for high loadings of starch, the weight loss 


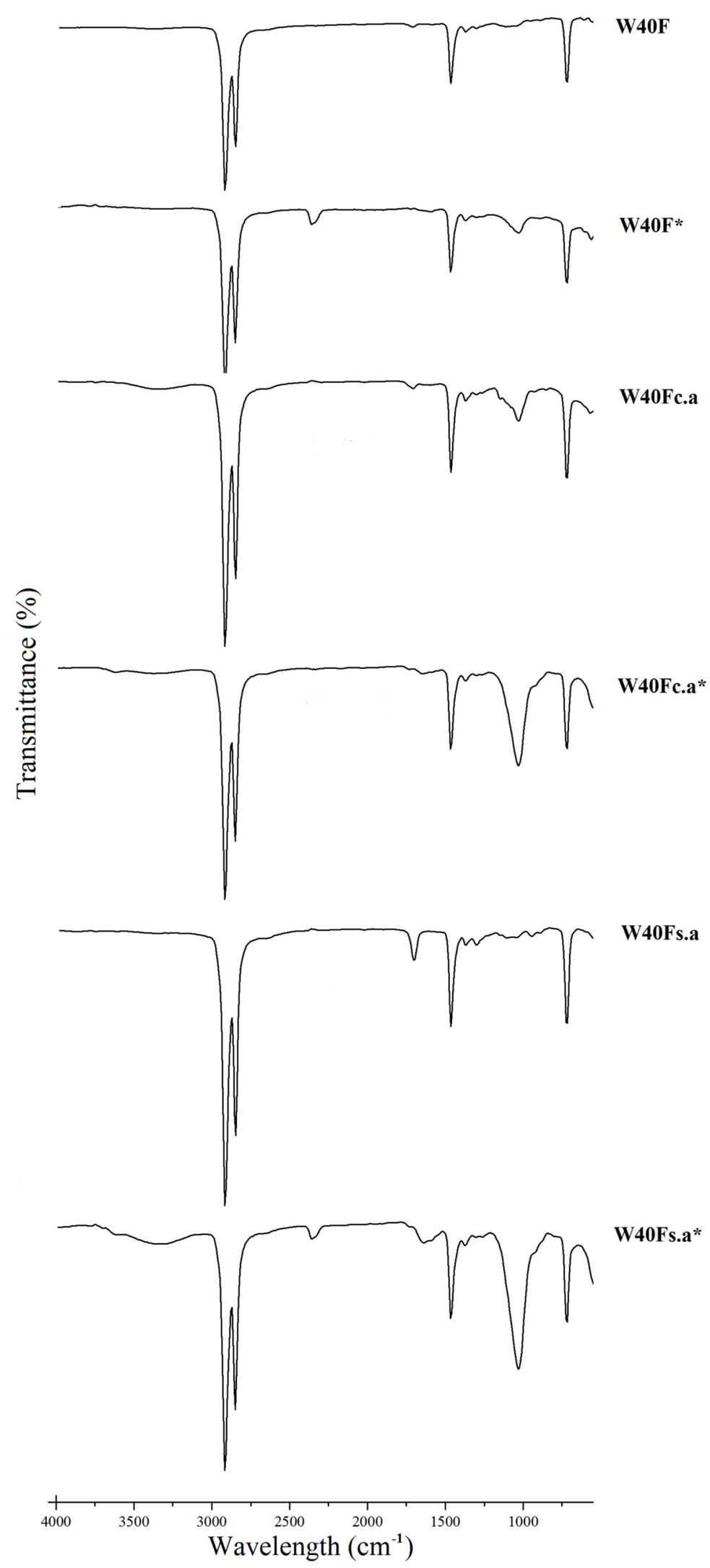

Figure 5. FTIR spectra of the ferric stearate group films with 40\% TPS loadings before and after soil burial treatment,* denotes after degradation. 

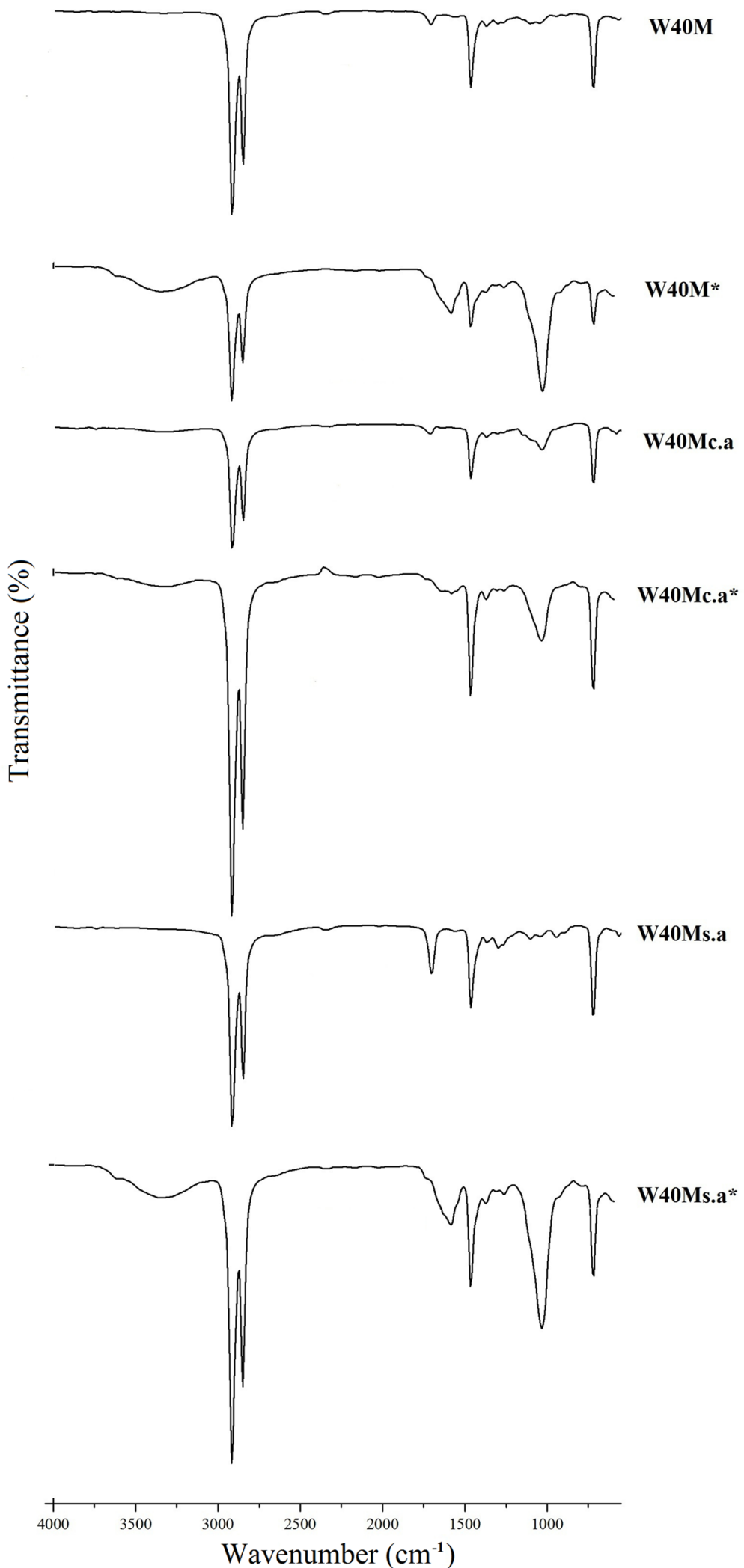

Figure 6. FTIR spectra of $40 \%$ TPS loaded manganese(II) stearate group films with additives before and after soil burial treatment, * denotes after degradation. 

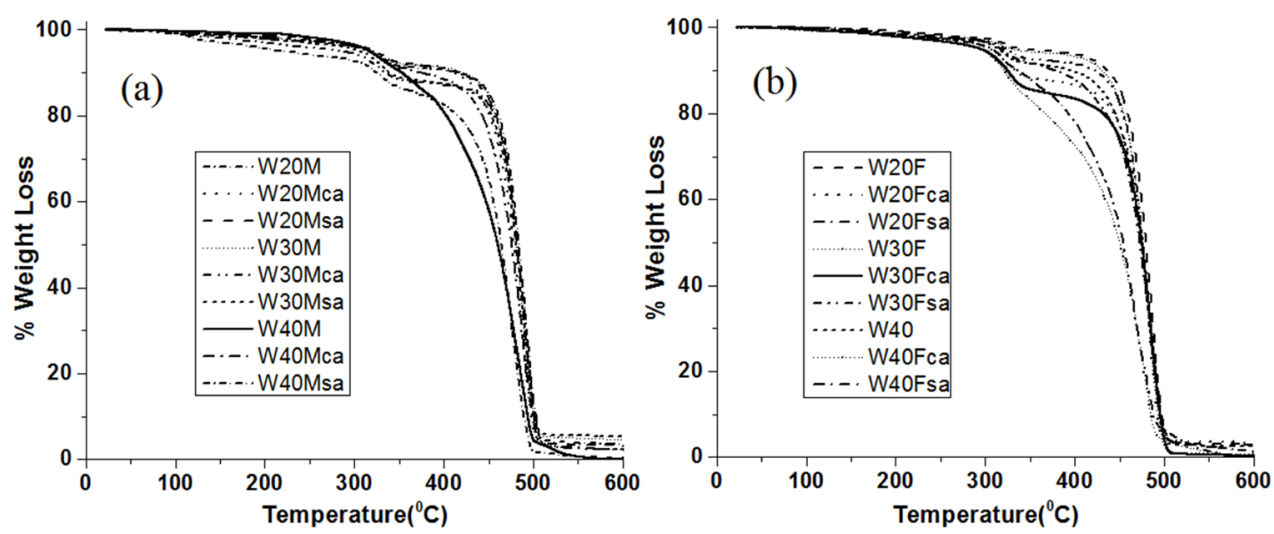

Figure 7. TGA curves of the blends after soil burial, a) manganese(II) stearate, b) ferric stearate groups.

for W40F, W40Fca and W40Fsa were 19.6\%, 27.1 $\%$ and $22.0 \%$ of their initial weight, respectively. Meanwhile, the weight loss for W40M, W40Mca and W40Msa were $17.3 \%, 19.1 \%$ and $17.6 \%$ of their initial weight. The samples with ferric stearate showed higher weight loss compared to the samples with manganese (II) stearate pro-oxidant and this can be attributed to the different oxidation states of the central metals. The central iron metal has +3 oxidation state in ferric stearate, whereas the manganese central metal has +2 oxidation state in manganese (II) stearate. A higher oxidation state of iron $\left(\mathrm{Fe}^{3+}\right)$ may cause the decomposition of hydroperoxides subsequently leads to the formation of carboxylic groups and these groups are very sensitive to the photo and thermal degradations. Some of the studies showed that the oxidation state of central metal play an important role in photoor thermooxidative degradations of LDPE films $[8,9]$. It was also found that the highest weight loss was observed in the blends with citric acid. Since citric acid caused badly acidolysis of starch, deteriorated the rigid structured of starch and eased the consumption by the micro-organisms, high amounts of degradation was evidenced for the samples with citric acid.

\section{FTIR Analysis After Soil Burial Treatment}

Figures 5 and 6 show the changes in the FTIR spectra of both ferric stearate and manganese (II) stearate pro-oxidant groups after degradation. The most significant changes were observed in the $-\mathrm{OH}$ stretching related broad band around

Table 3. Decomposition temperatures of blend films with manganese(II) stearate pro-oxidant before and after soil burial treatment.

\begin{tabular}{|c|c|c|c|c|c|c|}
\hline \multirow[b]{2}{*}{$\begin{array}{l}\text { Code of the } \\
\text { sample }\end{array}$} & \multicolumn{2}{|c|}{$\begin{array}{l}\text { Evaporation temperature of } \\
\text { glycerol }\left({ }^{\circ} \mathrm{C}\right)\end{array}$} & \multicolumn{2}{|c|}{$\begin{array}{l}\text { Degradation temperature of } \\
\text { wheat starch }\left({ }^{\circ} \mathrm{C}\right)\end{array}$} & \multicolumn{2}{|c|}{$\begin{array}{l}\text { Degradation } \\
\text { temperature of } \\
\operatorname{LDPE}\left({ }^{\circ} \mathrm{C}\right)\end{array}$} \\
\hline & $\begin{array}{l}\text { Before } \\
\text { soil } \\
\text { burial }\end{array}$ & $\begin{array}{l}\text { After } \\
\text { soil } \\
\text { burial }\end{array}$ & $\begin{array}{l}\text { Before } \\
\text { soil } \\
\text { burial }\end{array}$ & $\begin{array}{l}\text { After } \\
\text { soil } \\
\text { burial }\end{array}$ & $\begin{array}{l}\text { Before } \\
\text { soil } \\
\text { burial }\end{array}$ & $\begin{array}{l}\text { After } \\
\text { soil } \\
\text { burial }\end{array}$ \\
\hline W20M & 259 & - & 322 & 326 & 481 & 479 \\
\hline W20Mca & 246 & - & 326 & 330 & 481 & 486 \\
\hline W20Msa & 261 & - & 324 & 326 & 481 & 490 \\
\hline W30M & 258 & - & 321 & 328 & 481 & 489 \\
\hline W30Mca & 241 & - & 326 & 329 & 473 & 490 \\
\hline W30Msa & 258 & - & 325 & 329 & 481 & 489 \\
\hline W40M & 251 & - & 321 & 324 & 481 & 486 \\
\hline W40Mca & 238 & - & 321 & 326 & 481 & 489 \\
\hline W40Msa & 254 & - & 321 & 326 & 477 & 489 \\
\hline
\end{tabular}


Table 4. Decomposition temperatures of blend films with ferric stearate pro-oxidant before and after soil burial treatment.

\begin{tabular}{|c|c|c|c|c|c|c|}
\hline \multirow[b]{2}{*}{$\begin{array}{l}\text { Code of the } \\
\text { sample }\end{array}$} & \multicolumn{2}{|c|}{$\begin{array}{l}\text { Evaporation temperature of } \\
\text { glycerol }\left({ }^{\circ} \mathrm{C}\right)\end{array}$} & \multicolumn{2}{|c|}{$\begin{array}{l}\text { Degradation temperature of } \\
\text { wheat starch }\left({ }^{\circ} \mathrm{C}\right)\end{array}$} & \multicolumn{2}{|c|}{$\begin{array}{l}\text { Degradation } \\
\text { temperature of } \\
\operatorname{LDPE}\left({ }^{\circ} \mathrm{C}\right)\end{array}$} \\
\hline & $\begin{array}{l}\text { Before } \\
\text { soil } \\
\text { burial }\end{array}$ & $\begin{array}{l}\text { After } \\
\text { soil } \\
\text { burial }\end{array}$ & $\begin{array}{l}\text { Before } \\
\text { soil } \\
\text { burial }\end{array}$ & $\begin{array}{l}\text { After } \\
\text { soil } \\
\text { burial }\end{array}$ & $\begin{array}{c}\text { Before } \\
\text { soil } \\
\text { burial }\end{array}$ & $\begin{array}{l}\text { After } \\
\text { soil } \\
\text { burial }\end{array}$ \\
\hline W20F & - & - & 319 & 323 & 478 & 486 \\
\hline W20Fca & - & - & 328 & 323 & 479 & 484 \\
\hline W20Fsa & - & - & 319 & 319 & 479 & 468 \\
\hline W30F & 247 & - & 319 & 321 & 479 & 484 \\
\hline W30Fca & 242 & - & 328 & 326 & 477 & 486 \\
\hline W30Fsa & 247 & - & 319 & 326 & 477 & 484 \\
\hline W40F & - & - & 327 & 323 & 475 & 484 \\
\hline W40Fca & 249 & - & 330 & 324 & 481 & 479 \\
\hline W40Fsa & 251 & - & 321 & 319 & 481 & 484 \\
\hline
\end{tabular}

$3300 \mathrm{~cm}^{-1}$ for both citric acid and stearic acid blends. After 180 days soil burial treatment, with the removal of these compatibilizers by Coriolus versicolor fungi, more $-\mathrm{OH}$ group became free, and stronger peaks were observed during the degradation period. The characteristics $-\mathrm{C}=\mathrm{O}$ peaks around $1700 \mathrm{~cm}^{-1}$ for these compatibilizers were not observed after soil burial. FTIR spectra of the samples recovered from soil indicate that the thermoplastic starch is preferentially removed, leaving the LDPE matrix. Hence, the LDPE related characteristic peaks around 2916, 2844, 1464, 1032 and $717 \mathrm{~cm}^{-1}$ can be seen after the blend films degradation.

\section{Thermogravimetric Analysis After Soil Burial Treatment}

The TGA curves of the manganese (II) stearate and ferric stearate pro-oxidant added films, which were recovered from Coriolus versicolor inoculated soil, are presented in Figure $7 \mathrm{a}$ and $7 \mathrm{~b}$, respectively. The degradation temperatures of both manganese and ferric group blends for before and after soil burial treatment are given in Tables 3 and Table 4 respectively.

Before degradation the main decomposition temperature of pure LDPE was around $490^{\circ} \mathrm{C}$ and the addition of TPS into the LDPE lowered the decomposition temperature for blends. However, after the soil burial treatment the degradation temperature of the LDPE mostly increased. The increment in degradation temperature of LDPE might be the reduction of starch content after degradation. Exposure to fungi inoculated soil degradation of blend films caused to loss of some of glycerol and starch and then, the thermal degradation of LDPE occurred in higher temperature range.

In manganese(II) stearate group, the degradation stage which corresponds to the evaporation of glycerol was not seen in all blends, since the glycerol in TPS was removed during soil burial treatment (Table 3). A similar thermal behavior was also observed for the ferric stearate group (Table 4). Additionally, after degradation when compare the two pro-oxidants, the thermal stabilities of the blends with ferric stearate were slightly lower than the blends with manganese(II) stearate. The shift of the degradation temperature of the LDPE in somewhat higher degrees was due to the phase compatibility between the TPS and LDPE $[10,11]$.

\section{Mechanical Properties of Blends Before and After Soil Burial Treatment}

The effects of different compatibilizers and prooxidants in blend composition were evaluated by tensile tests. The mechanical properties of blends before and after soil burial treatment were given in Table 5. It is known that, fillers generally reduce 
Table 5. Mechanical properties of the blend films before and after soil burial treatment.

\begin{tabular}{|c|c|c|c|c|c|c|c|c|c|}
\hline \multirow{2}{*}{$\begin{array}{l}\text { Code of the } \\
\text { sample }\end{array}$} & \multicolumn{2}{|c|}{$\begin{array}{c}\text { Tensile Strength } \\
\text { (MPa) }\end{array}$} & \multicolumn{2}{|c|}{$\begin{array}{c}\text { Elongation } \\
\text { at Break } \\
(\%)\end{array}$} & \multirow{2}{*}{$\begin{array}{c}\text { Code } \\
\text { of the } \\
\text { sample }\end{array}$} & \multicolumn{2}{|c|}{$\begin{array}{c}\text { Tensile Strength } \\
\text { (MPa) }\end{array}$} & \multicolumn{2}{|c|}{$\begin{array}{c}\text { Elongation } \\
\text { at Break } \\
(\%)\end{array}$} \\
\hline & $\begin{array}{c}\text { Before } \\
\text { soil } \\
\text { burial }\end{array}$ & $\begin{array}{l}\text { After } \\
\text { soil } \\
\text { burial }\end{array}$ & $\begin{array}{c}\text { Before } \\
\text { soil } \\
\text { burial }\end{array}$ & $\begin{array}{l}\text { After } \\
\text { soil } \\
\text { burial }\end{array}$ & & $\begin{array}{l}\text { Before } \\
\text { soil } \\
\text { burial }\end{array}$ & $\begin{array}{c}\text { After } \\
\text { soil } \\
\text { burial }\end{array}$ & $\begin{array}{c}\text { Before } \\
\text { soil } \\
\text { burial }\end{array}$ & $\begin{array}{c}\text { After } \\
\text { soil } \\
\text { burial }\end{array}$ \\
\hline LDPE & 14.8 & - & 475.4 & - & LDPE & 14.8 & - & 475.4 & - \\
\hline W20 & 8.5 & 8.3 & 176.4 & 56.4 & W20 & 8.5 & 8.3 & 176.4 & 56.4 \\
\hline W20M & 9.0 & 7.4 & 195.1 & 57.1 & W20F & 8.1 & 6.4 & 183.2 & 71.7 \\
\hline W20Mca & 7.1 & 6.4 & 103.5 & 26.1 & W20Fca & 7.7 & 7.4 & 262.9 & 29.9 \\
\hline W20Msa & 8.5 & 9.3 & 248.1 & 30.9 & W20Fsa & 7.9 & 5.9 & 114.0 & 5.1 \\
\hline W30 & 6.9 & 6.4 & 65.2 & 34.6 & W30 & 6.9 & 6.4 & 65.2 & 34.6 \\
\hline W30M & 6.8 & 4.5 & 42.5 & 22.1 & W30F & 6.0 & 5.2 & 27.4 & 27.5 \\
\hline w30Mca & 5.5 & 5.6 & 63.6 & 17.8 & W30Fca & 6.7 & 5.5 & 211.4 & 61.9 \\
\hline w30Msa & 6.1 & 5.8 & 93.9 & 44.2 & w30Fsa & 5.2 & 6.3 & 26.9 & 6.6 \\
\hline W40 & 4.2 & 3.9 & 78.4 & 24.3 & W40 & 4.2 & 3.9 & 78.4 & 24.3 \\
\hline W40M & 6.1 & 5.7 & 29.1 & 8.4 & W40F & 5.3 & 5.2 & 23.7 & 14.7 \\
\hline W40Mca & 4.5 & 3.1 & 24.0 & 15.5 & W40Fca & 5.3 & 5.4 & 82.3 & 22.6 \\
\hline W40Msa & 5.6 & 3.1 & 22.2 & 4.1 & W40Fsa & 5.7 & 5.1 & 35.4 & 4.4 \\
\hline
\end{tabular}

the tensile strength of matrix due to the poor filler-matrix interactions [8]. This is also valid for high TPS content blends (W20, W30 and W40). Starch cannot elongate as LDPE and so, the drop in elongation at break (EB) can be seen in high loading of TPS. The effects of citric acid and stearic acid compatibilizers were also compared before degradation. Especially, for the ferric stearate prooxidant group, the samples with citric acid elongated more than the samples with stearic acid (EB values 262.9, 211.4, 82.3 for W2OFca:W30Fca:W40Fca blends). W40 Fca was the one having the highest EB value among the 40\% TPS containing films. Hence, citric acid provided better compatibility between TPS and LDPE phases (Table 5).

After the degradation of films in Coriolus versicolor inoculated soil, a comparison was done between the mechanical properties of manganese(II) stearate and ferric stearate groups. After degradation the mechanical properties of blends were deteriorated. The UTS and EB values decreased all through the manganese and ferric groups. However, this decay was seen more clearly for the ferric stearate pro-oxidant group. Faster decomposition occurred in ferric group which supported the weight loss results.

\section{CONCLUSION}

The effect of ferric stearate and manganese(II) stearate pro-oxidants on the degradation behavior of the TPS/LDPE blends were compared. The addition of the pro-oxidant in formulations of TPS/LDPE blends accelerated the degradation, particularly for ferric stearate pro-oxidant. Besides, using a small amount of citric acid compatibilizer together with ferric stearate caused to improved thermal stability of thermoplastic starch. During the degradation of blends in Coriolus versicolor inoculated soil, some of the TPS were consumed by fungi and so, the thermal degradation temperature of the remaining LDPE was increased. W4OFca blend showed the highest weight loss and the use of ferric stearate synergize with citric acid for increased weight loss. Because citric acid made starch partial acidolysis and reduced the size of the molecules as well as. After the soil burial, the mechanical properties of TPS/LDPE blends were very poor and the tensile strength and the elongation at break of the blends decreased greatly. 


\section{ACKNOWLEDGEMENT}

The authors thank to Prof. Dr. Erdal Bayramli (Chemistry Department, METU) for twin screw compounder instrument help and to Elif Kemeroz (Central Laboratory at METU) for thermal analysis.

\section{References}

1. A. Kapanen, E. Schettini, G. Vox, M. Itaavaara, Performance and Environmental Impact of Biodegradable Films in Agriculture: A Field Study on Protected Cultivation, Journal of the Polymers and the Environment, 16 (2008) 109-122.

2. J. Arutchelvi, M.Sudhakar, A. Arkatkar, Biodegradation of polyethylene and polypropylene, Polymer Degradation and Stability, 95 (2007) 1011-10.

3. J. Prachayawarakorn, P. Sangnitidej, P. Boonpasith, Properties of thermoplastic rice starch composites reinforced by cotton fiber or low-density polyethylene, Carbohydrate Polymers, 81 (2010) 425-433.

4. M. Koutny, J. Lemaire, A. Delort, Biodegradation of polyethylene films with prooxidant additives, Chemosphere, 64 (2006) 1243-1252.

5. Y. Orhan, H. Büyükgüngör, Enhancement of biodegradability of disposable polyethylene in controlled biological soil, International Biodeterioration \& Biodegradation, 45 (2000) 49-55.
6. R. Chandra, R. Rustgi, Biodegradation of maleated linear low-density polyethylene and starch blends, Polymer Degradation and Stability 56 (1997) 185-202.

7. E. Vargun, Z. Sisli, F. Yilmaz, H. Bas Sermenli, The effects of citric acid and stearic acid compatibilizers on the degradation behavior of TPS/LDPE blends for mulch films, Hacettepe Journal of Biology and Chemistry, 44(4) (2016) 463-476.

8. N.Sharma, L.P. Chang, Y.L. Chu, H. Ismail, U.S. Ishiaku, Z.A Mohd Ishak, A study on the effect of pro-oxidant on the thermo-oxidative degradation behaviour of sago starch filled polyethylene, Polymer Degradation and Stability, 71 (2001) 381-393.

9. P.K. Roy, P. Surekha, R. Raman, C. Rajagopal, Investigating the role of metal oxidation state on the degradation behavior of LDPE, Polymer Degradation and Stability, 94 (2009) 1033-1039.

10. W.Shujun, Y. Jiugao, Y. Jinglin, Preparation and characterization of compatible thermoplastic starch/ polyethylene blends, Polymer Degradation and Stability, 87 (2005) 395-401.

11. J. Prachayawarakorn, L. Hommanee, D. Phosee, P. Chairapaksatien, Property improvement of thermoplastic mung bean starch using cotton fiber and low-density polyethylene, Starch, 62 (2010) 435443. 